\title{
Role of ca 19-9 as a tumor marker in diagnosis and prognosis of pancreatic carcinoma and cholangiocarcinoma (A study of 46 cases)
}

\author{
Vaishnav M. ${ }^{1}$, Garg S. ${ }^{2}$, Popat $\mathrm{V}^{3}$ \\ ${ }^{1}$ Dr. Mitsu Vaishnav, Assistant Professor, Department of Pathology, Gujarat Adani Institute of Medical Science, Bhuj, \\ Kutchh, Gujarat, ${ }^{2}$ Dr. Sameep Garg, Assistant Professor, Department of Pathology, Gujarat Adani Institute of Medical \\ Science, Bhuj, Kutchh, Gujarat ${ }^{3}$ Dr. Vijay Popat, Associate Professor, Department of Pathology, Shri M.P. Shah \\ Medical college, Jamnagar, Gujarat, India
}

Address for Correspondence: Dr. Mitsu Vaishnav, Email Id: mitsuvaishnav2@gmail.com

\begin{abstract}
Introduction: Ca19-9 is currently the single most useful tumor marker for diagnosis and prognosis of pancreatic cancer and cholangiocarcinoma. Aim: The aim is to elucidate the importance of tumor marker ca 19-9 as a diagnostic and prognostic tool in pancreatic carcinoma and cholangio-carcinoma. Material and Methods: The time period of the study was from september-2012 to september- 2014. The patients were investigated pre-operatively and post operatively for ca 19-9 levels in their serum with the use of ELISA (enzyme linked immunosorbant assay) test. Results: Total 28 cases of pancreatic lesions were considered which included 24 cases of pancreatic ductal adenocarcinoma, It was observed that when preoperative serum CA 19-9 level was less than $37 \mathrm{u} / \mathrm{ml}$ median survival was 28 months. However when CA 19-9 level was more than $200 \mathrm{u} / \mathrm{ml}$, median survival was 6 months. Out of 18 cases studied in gallbladder tumors, 15 cases were of cholangiocarcinoma. Patients with pre-therapy serum CA 19-9 level was between $37-200 \mathrm{u} / \mathrm{ml}$ median survival was 23.25 months. When CA 19-9 level was more than $200 \mathrm{u} / \mathrm{ml}$, median survival was 10.25 months. Conclusion: Elevated level of ca 19-9 in pancreatic carcinoma and cholangiocarcinoma are associated with higher age group, male sex, higher histological grade, higher TNM staging and metastasis. Post operative ca 19-9 value has definitive prognostic value to detect any metastasis or recurrence in pancreatic carcinoma and cholangio- carcinoma. Therefore it can be concluded that ca 19-9 is an important tumor marker for pancreatic carcninoma and cholangio-carcinoma.
\end{abstract}

Keywords: CA19-9, Cholangiocarcinoma, Pancreatic Carcinoma, Tumor marker

\section{Introduction}

CA 19-9 although widely used for diagnosis of pancreatic carcinoma and cholangiocarcinoma there is no proper study to associate it with histological grade and TNM staging of pancreatic and cholangiocarcinoma. As a result this study was undertaken to determine the aforementioned association of CA 19-9.

CA 19-9 is underestimated in its use after curative surgery or chemotherapy of pancreatic carcinoma and cholangiocarcinoma. In this study we wanted to establish if CA 19-9 level both pre and post operatively was associated with survival rate in patients.

Manuscript received: $07^{\text {th }}$ May 2017

Reviewed: $15^{\text {th }}$ May 2017

Author Corrected: $25^{\text {th }}$ May 2017

Accepted for Publication: $31^{\text {st }}$ May 2017
The CA19-9 antigen is defined by an igg1 mouse monoclonal antibody raised against the human colonic carcinoma cell line SW 1116 by Koprowski and colleagues in 1979 [1]. Although the CA19-9 antibody was generated against a colorectal cancer cell line, it is found more frequently in the sera of patients with pancreatic carcinoma [2].

CA19-9 is currently the single most useful blood test in differentiating pancreatic cancer from chronic or recurring pancreatitis with a sensitivity ranging from $70-90 \%$ and specificity from $68-91 \%$ [3-6].

CA 19-9 is one of the most significant prognostic factors for both patients with resectable and those with 
un-resectable pancreatic carcinoma and cholangiocarcinoma. [7-9].

It has been shown that elevated serum concentrations of CA19-9 decrease after curative surgery and conversely that recurrent disease is often associated with an increase in the circulating level of this serum marker, which is a prerequisite for the use in follow-up of pancreatic carcinoma and cholangiocarcinoma. [3].

\section{Aims}

To elucidate the importance of tumor marker CA 19-9 as a diagnostic and prognostic tool in pancreatic carcinoma and cholangiocarcinoma.

Basic aim of present study is to study the role of tumor marker, CA19-9 test as a diagnostic and prognostic tool in pancreatic carcinoma and cholangiocarcinoma, monitor the response to treatment both surgical as well as radiotherapy, to follow up and analyze the correlation between CA 19-9 levels and clino-pathological features like age, stage of disease, size, grading, staging and metastasis.

\section{Material and Method}

Study Design: This is a prospective study of 46 cases. Study setting: The study was carried out in tertiary care centre affiliated with M.P. Shah Medical College. The patients were admitted in various wards like Surgery, Medicine and Radiotherapy.

Time period: The study was from September-2012 to September- 2014.

\section{Inclusion criteria}

1. Age 20years-100years

2. Both genders

3. Symptoms: Chief complaint of anorexia, malaise, nausea, vomiting, substantial weight loss, midepigastric pain, melena, hemetemesis, dysphagia, jaundice, epigastric lump etc. Was considered with USG, CT SCAN and MRI findings.

\section{Method used}

1. These patients were investigated for CA 19-9 levels in their serum with the use of ELISA (Enzyme Linked Immunosorbant Assay) test.

2. Both Pre operative and Post operative values were measured to see the changes in CA 19-9 value after tumor resection. Post operative value was measured after 30 days of surgical resection or 3 cycle of chemotherapy/Radiotherapy.

3. Preoperative serum Ca 19-9 level was also correlated with survival of patient.

4. Patients were followed up on regular basis through telephonic communication or/and hospital records.

5. Postoperative/ Post-therapy change in CA 19-9 was correlated with survival of patients.

Principle of the ca 19-9 assay:[10-20]:

1. Company's Name: Calbiotech CA 19-9 Elisa

2. The CA19-9 ELISA test is based on the principle of a solid phase enzyme-linked immunosorbent assay. The assay system utilizes a monoclonal antibody directed against a distinct antigenic determinant on the intact CA19-9 molecule is used for solid phase immobilization (on the micro-titer wells). Another CA 19-9 monoclonal antibody conjugated to horseradish peroxidase (HRP) is in the antibody-enzyme conjugate solution.

3. The concentration of CA19-9 is directly proportional to the colour intensity of the test sample. Absorbance is measured spectrophotometrically at $450 \mathrm{~nm}$.

Specimen collection and handling: [10-20]

1. Collect blood specimens and separate the serum.

2. Specimens may be refrigerated at $2-8^{\circ} \mathrm{C}$ for up to seven days or frozen for up to six months.

3. Avoid repetitive freezing and thawing of serum sample.

Calculations and results: [10-20]

1. Calculate the average absorbance values (A450) for each set of reference standards, control, and samples.

2. Construct a standard curve by plotting the mean absorbance obtained for each reference standard against its concentration in $\mathrm{U} / \mathrm{ml}$ via best fit quadratic on linear graph paper, with absorbance on the vertical (y) axis and concentration on the horizontal ( $\mathrm{x}$ ) axis.

3. Using the mean absorbance value for each sample, determine the corresponding concentration of CA19-9 in $\mathrm{U} / \mathrm{ml}$ from the standard curve.

Reference value [10-20]

1. Healthy men and women are expected to have CA19-9 assay values below $35 \mathrm{U} / \mathrm{ml}$.

2. The minimum detectable concentration of CA19-9 in this assay is estimated to be $10 \mathrm{U} / \mathrm{ml}$. 


\section{Observation and Result}

Pre- operative CA 19-9 was measured in every case for the purpose of diagnosis In some cases, post-operative CA 19-9 was measured and the patient was followed up for the length of the study to determine the prognosis and survival rate.

Table-I: Demographic factors of pancreatic lesions and gall- bladder lesion

\begin{tabular}{|c|c|c|c|}
\hline & Pancreatic lesions & Gall bladder lesions \\
\hline \multicolumn{2}{|c|}{ Total no of cases } & 28 & 18 \\
\hline \multirow{2}{*}{$\begin{array}{c}\text { Age of pateints } \\
\text { (in years) }\end{array}$} & $\mathbf{2 0 - 3 9}$ years & 3 & 0 \\
\cline { 2 - 4 } & $\mathbf{4 0 - 6 0 y e a r s}$ & 14 & 10 \\
\cline { 2 - 4 } & $\mathbf{> 6 0}$ years & 12 & 8 \\
\hline \multirow{2}{*}{ Sex of pateints } & Male & 18 & 7 \\
\cline { 2 - 4 } & Female & 10 & 7 \\
\hline
\end{tabular}

Table-II: Types of cases considered in the study

\begin{tabular}{|c|c|c|}
\hline Sr no & Types of cases & Number \\
\hline 1 & Acute pancreatitis & 2 \\
\hline 2 & Mucinous cystadenoma of pancreas & 1 \\
\hline 3 & Serous cystadenoma of pancreas & 1 \\
\hline 4 & Ductal adenocarcinoma of pancreas & 24 \\
\hline 5 & Choledocholithoasis/gall stones & 3 \\
\hline 6 & Gall bladder carcinoma/ cholangiocarcinoma & 15 \\
\hline
\end{tabular}

Table-III: Relationship between clinopathological factors and ca 19-9 values in pancreatic lesions / pancreatitis

\begin{tabular}{|c|c|c|c|c|}
\hline $\begin{array}{l}\mathrm{Sr} \\
\text { no }\end{array}$ & Clinopathological factors & Number & Ca 19-9 (mean) & Ca 19-9 (median) \\
\hline 1 & $\begin{array}{c}\text { Age : }(\mathrm{n}=28) \\
20-39 \mathrm{yrs} \\
40-59 \mathrm{yrs} \\
>60 \mathrm{yrs}\end{array}$ & $\begin{array}{c}03(10.7 \%) \\
14(50.1 \%) \\
11(39.28 \%)\end{array}$ & $\begin{array}{l}289.63 \\
232.03 \\
350.20\end{array}$ & $\begin{array}{l}250.9 \\
178.8 \\
350.2\end{array}$ \\
\hline 2 & $\begin{array}{c}\text { Sex: }(n=28) \\
\text { Male } \\
\text { Female }\end{array}$ & $\begin{array}{l}18(64.28 \%) \\
10(35.71 \%)\end{array}$ & $\begin{array}{l}395.85 \\
320.26\end{array}$ & $\begin{array}{l}218.85 \\
198.20\end{array}$ \\
\hline 3 & $\begin{array}{c}\text { Location: }(n=26) \\
\text { Head of pancreas } \\
\text { Body and tail }\end{array}$ & $\begin{array}{c}21(80.76 \%) \\
05(19.23 \%)\end{array}$ & $\begin{array}{l}445.08 \\
173.18 \\
\end{array}$ & $\begin{array}{l}253.6 \\
193.8 \\
\end{array}$ \\
\hline 5 & $\begin{array}{c}\text { Neoplasm: }(n=26) \\
\text { Benign } \\
\text { Malignant }\end{array}$ & $\begin{array}{l}02(14.28 \%) \\
24(85.71 \%)\end{array}$ & $\begin{array}{c}62.35 \\
420.35\end{array}$ & $\begin{array}{c}62 \\
252.25\end{array}$ \\
\hline 7 & $\begin{array}{c}\text { Staging: }(n=24) \\
\text { Stage } i \\
\text { Stage iia } \\
\text { Stage iib } \\
\text { Stage iii } \\
\text { Stage iv }\end{array}$ & $\begin{array}{c}1(4.16 \%) \\
5(20.83 \%) \\
5(20.83 \%) \\
5(20.83 \%) \\
8(33.33 \%)\end{array}$ & $\begin{array}{c}11 \\
214.78 \\
172.70 \\
337.6 \\
806.48\end{array}$ & $\begin{array}{c}11 \\
186.8 \\
193.8 \\
282.8 \\
627.2\end{array}$ \\
\hline 8 & $\begin{array}{c}\text { Metastasis: }(\mathrm{n}=24) \\
\text { Only lymph node } \\
\text { Only distant organs } \\
\text { Both ln and distant organ } \\
\text { metastasis } \\
\text { No metastasis }\end{array}$ & $\begin{array}{c}09(37.5 \%) \\
04(16.66 \%) \\
04(16.66 \%) \\
07(29.13 \%)\end{array}$ & $\begin{array}{c}617.14 \\
806.71 \\
1339 \\
183.92\end{array}$ & $\begin{array}{c}362.2 \\
627.2 \\
1402.2 \\
186.8\end{array}$ \\
\hline
\end{tabular}


Total 28 cases of pancreatic lesions were considered which included 24 cases of pancreatic ductal adenocarcinoma, 2 cases of acute pancreatitis, 1 case of mucinous cystadenoma of pancreas and 1 case of serous cystadenoma of pancreas.

Out of 18 cases studied in gallbladder tumors, three cases of choledocholithiasis were considered and the rest 15 cases were of gall bladder carcinoma/cholangiocarcinoma.

Table-IV: Relationship between clinopathological factors and ca 19-9 values in gall bladder tumors and choledocholithiasis

\begin{tabular}{|c|c|c|c|c|}
\hline $\begin{array}{l}\text { Sr } \\
\text { no }\end{array}$ & Clinopathological factors & Number & Ca 19-9 (mean) & Ca 19-9(median) \\
\hline 1 & $\begin{array}{c}\text { Age : }(\mathrm{n}=18) \\
20-39 \mathrm{yrs} \\
40-59 \mathrm{yrs} \\
>60 \mathrm{yrs}\end{array}$ & $\begin{array}{c}0 \\
10(55.55 \%) \\
08(44.44 \%)\end{array}$ & $\begin{array}{c}00 \\
161.27 \\
301.225\end{array}$ & $\begin{array}{c}00 \\
86.6 \\
213.05\end{array}$ \\
\hline 2 & $\begin{array}{c}\text { Sex: }(n=18) \\
\text { Male } \\
\text { Female }\end{array}$ & $\begin{array}{l}11(61.11 \%) \\
07(38.88 \%)\end{array}$ & $\begin{array}{l}316.45 \\
166.32\end{array}$ & $\begin{array}{c}40 \\
120\end{array}$ \\
\hline 3 & $\begin{array}{c}\text { Neoplasm: }(n=18) \\
\text { Benign } \\
\text { Malignant } \\
\end{array}$ & $\begin{array}{l}03(16.66 \%) \\
15(83.33 \%) \\
\end{array}$ & $\begin{array}{c}28.66 \\
254.43 \\
\end{array}$ & $\begin{array}{c}23 \\
123.8 \\
\end{array}$ \\
\hline 5 & $\begin{array}{c}\text { Staging: }(\mathbf{n}=\mathbf{1 5}) \\
\text { Stage i } \\
\text { Stage ii } \\
\text { Stage iiia } \\
\text { Stage iiib } \\
\text { Stage iva } \\
\text { Stage ivb }\end{array}$ & $\begin{array}{c}00 \\
04(26.66 \%) \\
05(33.33 \%) \\
03(20 \%) \\
00 \\
03(20 \%) \\
\end{array}$ & $\begin{array}{c}217.87 \\
276.2 \\
178.16 \\
- \\
383.16\end{array}$ & $\begin{array}{c}109.45 \\
120 \\
118.2 \\
- \\
302.3\end{array}$ \\
\hline 6 & $\begin{array}{c}\text { Metastasis: }(\mathbf{n}=\mathbf{1 5}) \\
\text { only lymph node } \\
\text { Only distant organs } \\
\text { Both ln and other organ } \\
\text { metastasis } \\
\text { No metastasis }\end{array}$ & $\begin{array}{c}03(20 \%) \\
01(6.6 \%) \\
02(13.33 \%) \\
09(60 \%)\end{array}$ & $\begin{array}{c}276.34 \\
383.16 \\
423.6 \\
\\
283.6\end{array}$ & $\begin{array}{l}123.8 \\
302.2 \\
423.6 \\
\\
120\end{array}$ \\
\hline
\end{tabular}

Table-V: Preoperative serum ca 19-9 level co-related with survival in pancreatic carcinoma and cholangiocarcinoma

\begin{tabular}{|c|c|c|}
\hline Ca 19-9 level & $\begin{array}{c}\text { Median survival in pancreatic } \\
\text { carcinoma (months) }\end{array}$ & $\begin{array}{c}\text { Median survival in cholangiocarcinoma } \\
\text { (months) }\end{array}$ \\
\hline$<\mathbf{3 7} \mathbf{~ u} / \mathbf{m l}$ & 28 & -- \\
\hline $\mathbf{3 7 -}<\mathbf{2 0 0 u} / \mathbf{m l}$ & 18 & 23.25 \\
\hline$>\mathbf{2 0 0} \mathbf{~ u ~} / \mathbf{m l}$ & 6 & 10.25 \\
\hline
\end{tabular}

Pre-operative serum CA 19-9 level was measured in all cases of pancreatic carcinoma and 12 cases were followed up to determine their median survival. It was observed that when preoperative serum CA 19-9 level was less than $37 \mathrm{u} / \mathrm{ml}$ median survival was 28 months.

When serum CA 19-9 level was between 37 -200 u/ml survival decreased upto 18 months. However when CA 19-9 level was more than $200 \mathrm{u} / \mathrm{ml}$, median survival was 6 months. Thus, preoperative serum CA 19-9 level plays a role in determining survival in patients with pancreatic carcinoma.

Out of 15 cases of gall bladder carcinoma/cholangiocarcinoma, 08 cases were followed up. No case with preoperative serum CA 19-9 level $<37 \mathrm{u} / \mathrm{ml}$ was followed. Patients with pre-therapy serum CA 19-9 level was between $37-200 \mathrm{u} / \mathrm{ml}$ median survival was 23.25 months. However when CA 19-9 level was more than $200 \mathrm{u} / \mathrm{ml}$, median survival was 10.25 
months. Thus, preoperative serum CA 19-9 level plays a role in determining survival in gall bladder carcinoma/cholangiocarcinoma

Table-VI: Postoperative changes in serum ca 19-9 co-related with survival in pancreatic carcinoma and cholangiocarcinoma

\begin{tabular}{|c|c|c|}
\hline Ca 19-9 level & $\begin{array}{c}\text { Median survival in pancreatic } \\
\text { carcinoma (months) }\end{array}$ & $\begin{array}{c}\text { Median survival in } \\
\text { cholangiocarcinoma (months) }\end{array}$ \\
\hline$>\mathbf{5 0} \%$ decrease in level & 18 & 20 \\
\hline$<\mathbf{5 0} \%$ decrease in level & 6 & 13.5 \\
\hline
\end{tabular}

Out of 24 cases of pancreatic carcinoma, 12 cases were followed up and their post-therapy changes in serum ca 19-9 level were measured. Their survival was considered according to post-operative or post-therapy CA 19-9 levels.

Out of 12 patients who were followed up on regular basis, their postoperative/ post therapy CA 19-9 value was measured and percentage of decrease in post-therapy CA 19-9 was compared with survival of patients. It was observed that when post-therapy CA $19-9$ level decreases more than $50 \%$ of pre-therapy level survival rate increases and the median survival is 18 months.

However, if post-therapy decreases in CA 19-9 level is less than $50 \%$, they are usually patients with metastasis or reoccurrence, and their survival rate is less. Median survival for such cases is 6 months.

Out of 08 patients who were followed up on regular basis, their postoperative/ post therapy CA 19-9 value was measured and percentage of decrease in post-therapy CA 19-9 was compared with survival of patients. It was observed that when post-therapy CA $19-9$ level decreases more than $50 \%$ of pre-therapy level survival rate increases and the median survival is 20 months.

However, if post-therapy decreases in CA 19-9 level is less than $50 \%$, they are usually patients with metastasis or reoccurrence, and their survival rate is less. Median survival for such cases is 13.5 months.

Table-VII: Statistical analysis of ca 19-9 in diagnosis of pancreatic carcinoma and cholangiocarcinoma (when cut of value for ca $19-9$ is $37 \mathrm{u} / \mathrm{ml}$ )

\begin{tabular}{|c|c|c|c|c|}
\hline & Sensitivity & Specificity & Positive Predictive value & Negative predictive Value \\
\hline $\begin{array}{c}\text { Pancreatic } \\
\text { Carcinoma }\end{array}$ & $87.50 \%$ & $50.00 \%$ & $91.30 \%$ & $40.00 \%$ \\
\hline $\begin{array}{c}\text { Cholangio } \\
\text { Carcinoma }\end{array}$ & $80 \%$ & $66.67 \%$ & $92.31 \%$ & $40.00 \%$ \\
\hline
\end{tabular}

When cut off value for ca $19-9$ value is $37 \mathrm{u} / \mathrm{ml}$ :

1) Sensitivity: it is the probability that test result will be 'positive' when disease is present. Serum ca 19-9 level is most sensitive for pancreatic carcinoma followed by cholangiocarcinoma.

2) Specificity: it is probability that the test will be 'negative, when disease is absent. This is because many benign conditions like pancreatitis show an elevation in serum ca 19-9 level (false positives)

3) Positive predictive rate: it is probability that the disease is present when test is positive.

4) Negative predictive value: it is probability that the disease is not present when the test is negative. It is $40 \%$ for both pancreatic carcinoma and cholangiocarcinoma. 


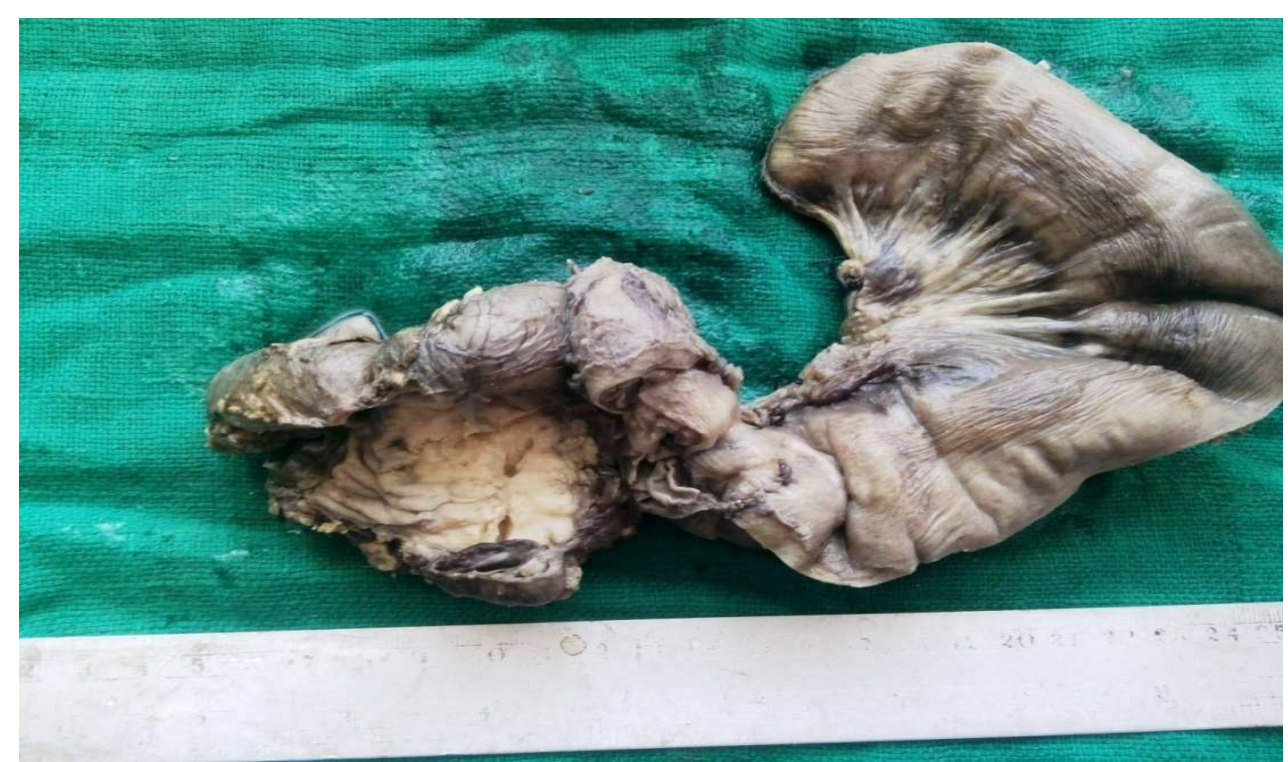

Figure-1: Gross appearance of pancreatic carcinoma showing the tumor mass protruding in tubular lumen

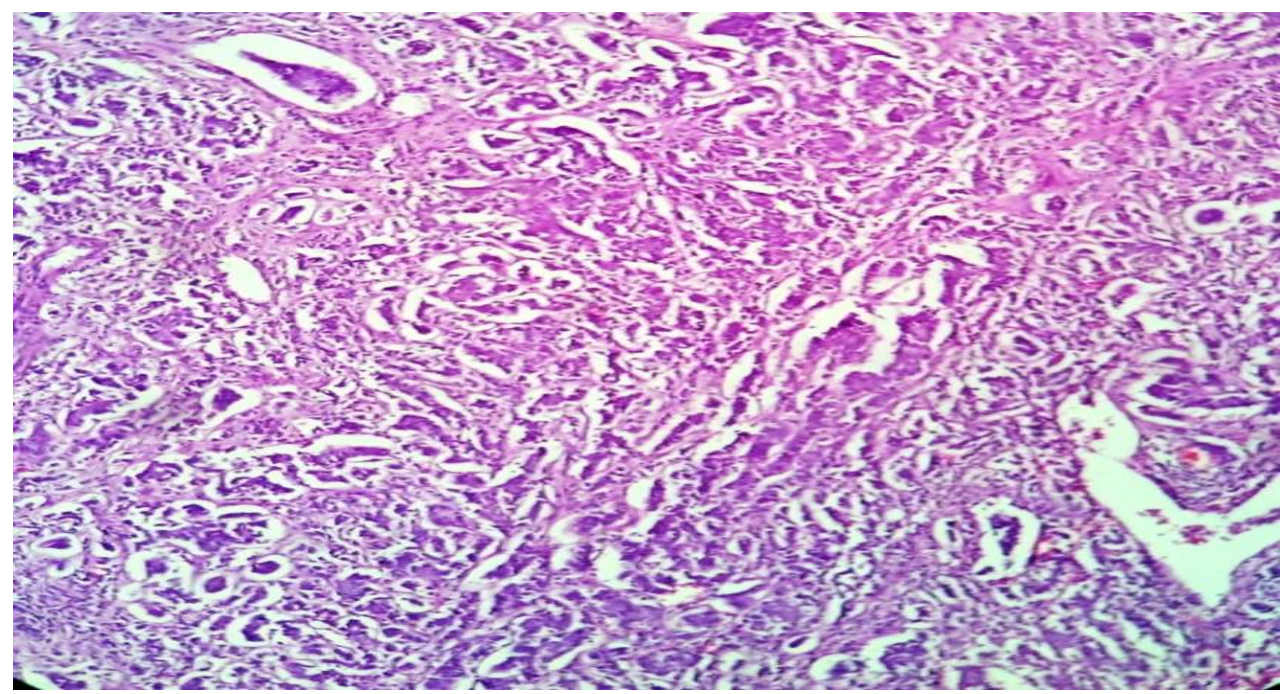

Figure-2: Histopathology of pancreatic ductal adenocarcinoma, well differentiated type (H \& E X40)

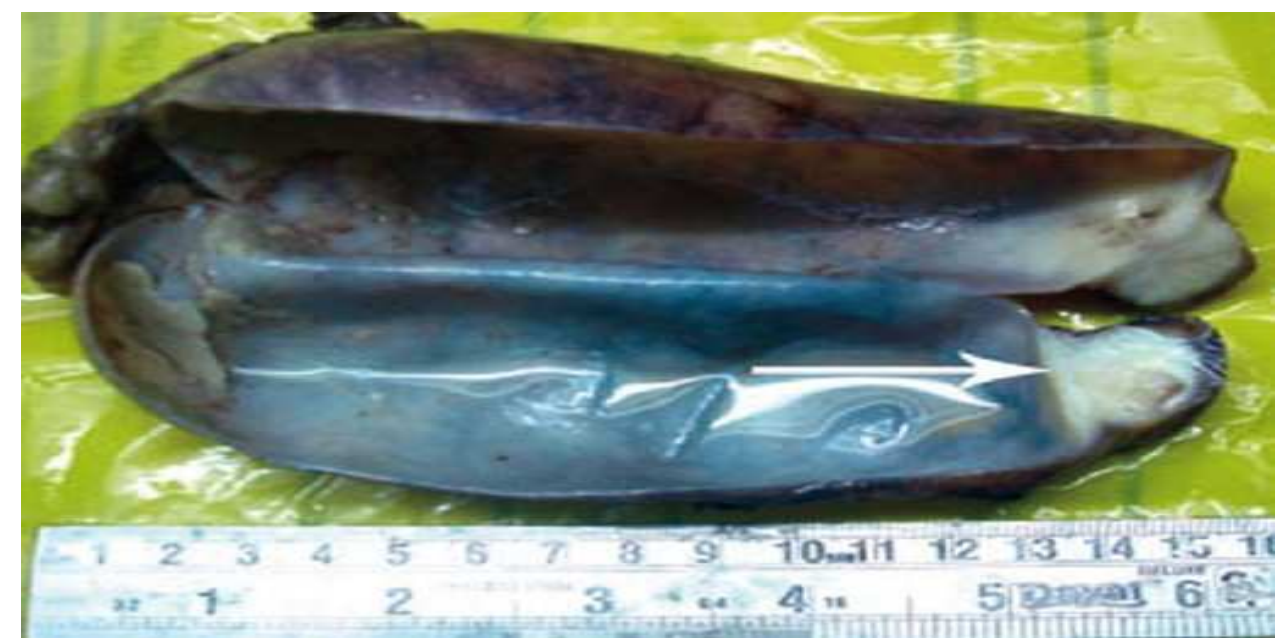

Figure-3: Gross of cholangiocarcinoma showing whitish mass at neck of gall bladder 


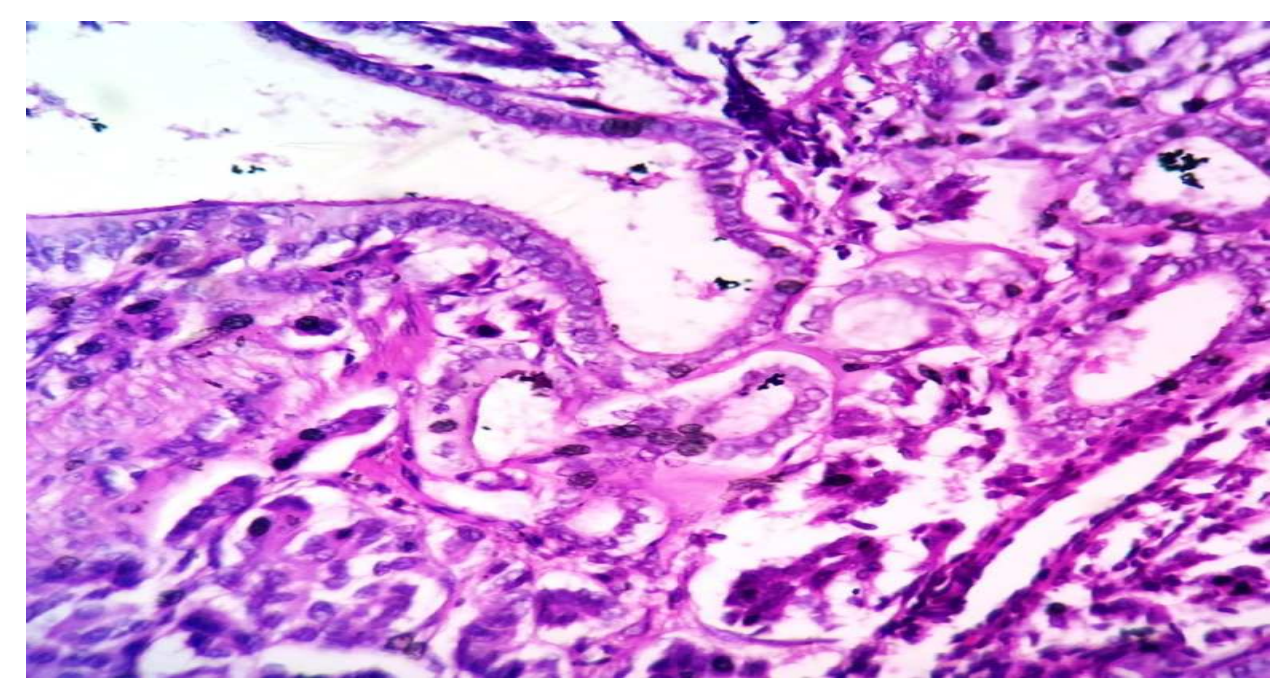

Figure-4: histopathology of well differentiated cholangiocarcinoma. (h \& e x 40)

\section{Discussion}

Elisa test to measure ca 19-9 is reliable, sensitive, rapid and cost effective test. Ca $19-9$ is the preferred tumor marker of choice for detection of tumor recurrence after surgery or radiotherapy in cases of pancreatic carcinoma and cholangiocarcinoma with pretreatment elevated ca 19-9. It is also a good serum marker for monitoring response to treatment for patients having pancreatic carcinoma and cholangiocarcinoma.

Pancreatic cancer- Regarding Age and sex incidence of patients pancreatic carcinoma, in the study of dong et al [21], more than $50 \%$ of patients were above the age of 60 years and male to female ratio in the study was $1.2: 1$ while in present study $60 \%$ of patients were below the age of 60 years and male to female ratio was 1.8:1. This discrepancy in percentage was seen because of large sample size and varied age group in study of dong et al [21].

The Median value of CA 19-9 was compared with staging of pancreatic carcinoma in various studies. In present study The median value of CA 19-9 for Stage Ia is $11 \mathrm{u} / \mathrm{ml}$, Stage iia and iib is 186 and $194 \mathrm{U} / \mathrm{ml}$ respectively and Stage III pancreatic carcinoma is 282 $\mathrm{U} / \mathrm{ml}$ while for Stage IV pancreatic carcinoma is 627 $\mathrm{U} / \mathrm{ml}$. Hence there is significant proportional increase in CA 19-9 with stage of pancreatic carcinoma. It was observed in all studies that the median value of CA 19-9 increased as stage of disease increases. The maximum value of CA 19-9 was observed in Stage IV patients. The median values at various stages in present study was comparable to the studies of Pleskow et al [23],
Safi et al [24], and Ferrone et al [25] while the median values shows a large amount of discrepancy with median values of studies Jiang et al [22], Kim et al [26] and Dong et al [21].

It was because of criteria of inclusion of subjects, large sample size, geographic distribution and present study had only included resectable pancreatic cancers.

It was observed in the present study that mean survival rate of patient decreased as preoperative value of $\mathrm{CA}$ 19-9 increased. Hence preoperative serum CA 19-9 has a prognostic significance. The results of present study were comparable to Berger et al [27], Ferrone et al [25] and Waraya et al [28].

In present study, percentage of change in serum CA 199 value after resection or radio/chemo-therapy was considered with survival of patient. It was observed that mean survival of patient was more if postoperative serum CA 19-9 value decreased to less than $50 \%$ of original preoperative value. These findings were consistent with other studies like Saad et al [29], Stemmler et al [30] and Reni et al [31]. The correlation between all the studied definitely suggest there is significance in change of serum CA 19-9 level postoperatively with survival of patients.

In present study the sensitivity was $87.50 \%$ while specificity was $50 \%$ for diagnosis of pancreatic carcinoma. The sensitivity was comparable to other studies which are Haglund et al [32], Cwik et al [33] 
and Ma et al [34]. While the specificity is showing discrepancy. This is because in the study of Haglund et al [32], there was a large sample size. In comparision with Cwik et al [33], the problem was large sample size and he considered only malignant lesions while in present study sample size is small and both benign and malignant conditions were considered. In the study $\mathrm{Ma}$ et al differs from present study because he didn't consider any benign conditions only healthy individuals and patients with pancreatic cancer were considered [34].

Gall bladder carcinoma/cholangiocarcinoma- Qin et al [35] study included 35 cases of cholangiocarcinoma and 92 cases of benign biliary disease. Present study includes 15 cases of cholangiocarcinoma and 3 cases of benign biliary disease. The mean age for cholangiocarcinoma in study of Qin et al [35], was 60.37 years while in the present study the mean age was 58.86 years. Both the studies are comparable. Qin et al, 2014 studied patients with Male to Female (M: F) ratio of $1.8: 1$. In present study the male to female ratio was 1.6: 1 which is quite comparable [35].

In present study 15 cases were studied and it was observed that when serum CA 19-9 level was less than $300 \mathrm{u} / \mathrm{ml}$ median survival was 23.25 months and when CA 19-9 was more than $300 \mathrm{u} / \mathrm{ml}$ median survival decreased to 10.25 months. Similar observation was made in study of Harder et al [36]. Thus, it is quite comparable.

In present study sensitivity was $80 \%$ and specificity was $66.66 \%$ while in study of Qin et al $\mathbf{2 0 1 4}$ it has sensitivity of $77.41 \%$ and specificity was $84.78 \%$ for cholangiocarcinoma [35]. While in present study, sensitivity was comparable to afore mentioned study at $77.41 \%$. But specificity of present study was less as compared to study done by Qin et al [35]. The reason for this being, specificity takes into account 'true negative' and 'false positive'. In present study the 'false positive' was more because, it considered only 3 cases of benign disease of gall bladder which were choledocholithiasis while 92 cases were studied in study of Qin et al [35], 2014 and they included bile duct stricture, choledocholithiasis, cholecystic poly and chronic cholecystitis. Present study observed an increase in serum ca 19-9 level in benign disease of gall bladder. Mean value of serum CA 19-9 in benign disease in present study was 28.66 while it was 13.38 in Qin et al [35], 2014. As a result specificity in present study was less as compared to Qin et al [35], 2014, mainly as type of benign cases considered were different.

\section{Funding: Nil, Conflict of interest: None Permission of IRB: Yes}

\section{References}

1. Eskelinen M, Haglund U. Developments in serologic detection of human pancreatic adenocarcinoma. Scand $\mathbf{J}$ Gastroenterol. 1999 Sep;34(9):833-44.

2. Herlyn, M.; Sears, H.F.; Steplewski, Z.; Koprowski, H. Monoclonal antibody detection of a circulating tumor-associated antigen. I. Presence of antigen in sera of patients with colorectal, gastric, and pancreatic carcinoma. J. Clin. Immunol. 1982; volume 2 issue 2;135-140.

3. Audisio RA, Veronesi P, Maisonneuve P, Chiappa A, Andreoni B, Bombardieri E, Geraghty JG. Clinical relevance of serological markers in the detection and follow-up of pancreatic adenocarcinoma. Surg Oncol. 1996 Apr;5(2):49-63.

4. Aoki H, Ohnishi H, Hama K, Ishijima T, Satoh Y, Hanatsuka K, Ohashi A, Wada S, Miyata T, Kita H, Yamamoto H, Osawa H, Sato K, Tamada K, Yasuda H, Mashima H, Sugano K. Autocrine loop between TGFbeta1 and IL-1beta through Smad3- and ERKdependent pathways in rat pancreatic stellate cells. Am J Physiol Cell Physiol. 2006 Apr;290(4):C1100-8. Epub 2005 Dec 21.

5. Okusaka, T.; Okada, S.; Ishii, H.; Nose, H.; Nakasuka, H.; Nakayama, H.; Nagahama, H. Clinical response to systemic combined chemotherapy with 5fluorouracil and cisplatin (FP therapy) in patients with advanced pancreatic cancer. Jpn. J. Clin. Oncol. 1996;26;215-220.

6. Tanaka, M.; Chari, S.; Adsay, V.; Fernandez-del Castillo, C.; Falconi, M.; Shimizu, M.; Yamaguchi, K.; Yamao, K.; Matsuno, S. International consensus guidelines for management of intraductal papillary mucinous neoplasms and mucinous cystic neoplasms of the pancreas. Pancreatology 2006, 6(1-2);17-32.

7. Steinberg W. The clinical utility of the CA 19-9 tumor-associated antigen. Am J Gastroenterol. 1990 Apr;85(4):350-5. 
8. Goonetilleke KS, Siriwardena AK. Systematic review of carbohydrate antigen (CA 19-9) as a biochemical marker in the diagnosis of pancreatic cancer. Eur J Surg Oncol. 2007 Apr;33(3):266-70. Epub 2006 Nov 9.

9. Kobayashi, T.; Kawa, S.; Tokoo, M.; Oguchi, H.; Kiyosawa, K.; Furuta, S.; Kanai, M.; Homma, T. Comparative study of CA-50 (time-resolved fluoroimmunoassay), Span-1, and CA19-9 in the diagnosis of pancreatic cancer. Scand. J. Gastroenterol. 1991; volume 26 issue 7; 787-797.

10. Glenn J, Steinberg WM, Kurtzman SH, Steinberg SM, Sindelar WF. Evaluation of the utility of a radioimmunoassay for serum CA 19-9 levels in patients before and after treatment of carcinoma of the pancreas. J Clin Oncol. 1988 Mar;6(3):462-8.

11. Hayakawa $\mathrm{T}$, Kondo $\mathrm{T}$, Shibata $\mathrm{T}$, Hamano $\mathrm{H}$, Kitagawa M, Sakai Y, Ono H. Sensitive serum markers for detecting pancreatic cancer. Cancer. 1988 May 1;61(9):1827-31.

12. Koprowski H, Herlyn M, Steplewski Z, Sears HF. Specific antigen in serum of patients with colon carcinoma. Science. 1981 Apr 3;212(4490):53-5.

13. Malesci, A., Tommasini, M.A., Bonato, C. et al. Determination of CA19-9 antigen in serum and pancreatic juice for differential diagnosis of pancreatic adenocarcinoma from chronic pancreatitis. Gastroenteroglogy 1987 Jan; 92(1):60.

14. Safi, F, Roscher, R., Bittner, R., et al. High sensitivity and specificity of CA 19-9 for pancreatic carcinoma in comparison to chronic pancreatitis. Serological and immunohistochemical findings. Pancreas 1987; 2(4):398-403.

15. Steinberg W. The clinical utility of the CA 19-9 tumor-associated antigen. Am J Gastroenterol. 1990 Apr;85(4):350-5.

16. Steinberg WM, Gelfand R, Anderson KK, Glenn J, Kurtzman SH, Sindelar WF, Toskes PP. Comparison of the sensitivity and specificity of the CA19-9 and carcinoembryonic antigen assays in detecting cancer of the pancreas. Gastroenterology. 1986 Feb;90(2):343-9.

17. Takasaki, H., Uchida, E., Tempero, M.A., et al. Correlative study on expression of CA 19-9 and DU-
Pan-2 in tumor tissue and in serum of pancreatic cancer patients. Cancer Research 1988 March; 48:1435-.

18. Tatsuta, M., Yamamura, H., Iishi H., et al. Values of CA19-9 in the serum, pure pancreatic juice and aspirated pancreatic material in the diagnosis of malignant pancreatic tumor. Cancer 1985 Dec 1; 56(11):2669-73.

19. Wang, T.H. Lin, J.W., Chen, D.S., et al. Noninvasive diagnosis of advanced panceatic cancer by real-time ultrasonography, carcinoembryonic antigen, and carbohydrate antigen 19-9. Pancreas 1986; 1(3):219-23.

20. Strom BL, Maislin G, West SL, et al. Serum CEA and CA19-9: potential future diagnostic or screening tests for gallbladder cancer? Int. J. Cancer 1990 May $15 ; 45(5): 821-4$.

21. Dong et al. World Journal of Surgical Oncology 2014;12:171; doi: 10,1186/1477-7819-12-171.

22. Jiang JT, Wu CP, Deng HF, Lu MY, Wu J, Zhang HY, Sun WH, Ji M. Serum level of TSGF, CA242 and CA19-9 in pancreatic cancer. World J Gastroenterol. 2004 Jun 1;10(11):1675-7.

23. Pleskow DK, Berger HJ, Gyves J, Allen E, McLean A, Podolsky DK. Evaluation of a serologic marker, CA19-9, in the diagnosis of pancreatic cancer. Ann Intern Med. 1989 May 1;110(9):704-9.

24. Safi F, Schlosser W, Kolb G, Beger HG. Diagnostic value of CA 19-9 in patients with pancreatic cancer and nonspecific gastrointestinal symptoms. J Gastrointest Surg. 1997 Mar-Apr;1(2):106-12.

25. Ferrone CR, Finkelstein DM, Thayer SP, Muzikansky A, Fernandez-delCastillo C, Warshaw AL. Perioperative CA19-9 levels can predict stage and survival in patients with resectable pancreatic adenocarcinoma. J Clin Oncol. 2006 Jun 20;24(18):2897-902.

26. Kim YC, Kim HJ, Park JH, Park DI, Cho YK, Sohn CI, Jeon WK, Kim BI, Shin JH. Can preoperative CA19-9 and CEA levels predict the resectability of patients with pancreatic adenocarcinoma? J Gastroenterol Hepatol. 2009 Dec;24(12):1869-75. doi: 10.1111/j.1440-1746.2009.05935.x. 
27. Berger AC, Meszoely IM, Ross EA, Watson JC, Hoffman JP. Undetectable preoperative levels of serum CA 19-9 correlate with improved survival for patients with resectable pancreatic adenocarcinoma. Ann Surg Oncol. 2004 Jul;11(7):644-9. Epub 2004 Jun 14.

28. Waraya M, Yamashita K, Katagiri H, Ishii K, Takahashi Y, Furuta K, et al. Preoperative serum CA199 and dissected peripancreatic tissue margin as determiners of long-term survival in pancreatic cancer. Ann Surg Oncol 2009 May;16(5):1231-40.doi: 10.1245/s10434-009-0415-7.

29. Saad ED, Machado MC, Wajsbrot D, Abramoff R, Hoff PM, Tabacof J, et al. Pretreatment CA 19-9 level as a prognostic factor in patients with advanced pancreatic cancer treated with gemcitabine. Int $\mathbf{J}$ Gastrointest Cancer,vol.32,no.1, 2002;35-41.

30. Stemmler J, Stieber P, Szymala AM, Schalhorn A, Schermuly MM, Wilkowski R, Helmberger T, Lamerz R, Stoffregen C, Niebler K, Garbrecht M, Heinemann V. Are serial CA 19-9 kinetics helpful in predicting survival in patients with advanced or metastatic pancreatic cancer treated with gemcitabine and cisplatin? Onkologie. 2003 Oct;26(5):462-7.

31. Reni M, Cereda S, Balzano G, Passoni P, Rognone A, Fugazza C, et al. Carbohydrate antigen 19-9 change during chemotherapy for advanced pancreatic adenocarcinoma. Cancer 2009 Jun 15;115(12):26309.doi: 10.1002/cncr.24302.

32. Haglund C, Roberts PJ, Kuusela P, Scheinin TM, Mäkelä O, Jalanko H. Evaluation of CA 19-9 as a serum tumour marker in pancreatic cancer. Br J Cancer. 1986 Feb;53(2):197-202.

33. Cwik G, Wallner G, Skoczylas T, Ciechanski A, Zinkiewicz K. Cancer antigens 19-9 and 125 in the differential diagnosis of pancreatic mass lesions. Arch Surg. 2006 Oct;141(10):968-73; discussion 974.

34. Z.Ma et al. An evaluation of the diagnostic value of CA19-9 and CEA levels in patients with pancreatic cancer. Journal of Nanjing Medical University, 2009 may, 23 (3): 199 -202.

35. Qin XL, Wang ZR, Shi JS, Lu M, Wang L, He QR. Utility of serum CA19-9 in diagnosis of cholangiocarcinoma: in comparison with CEA. World J Gastroenterol. 2004 Feb 1;10(3):427-32.

36. Jan Harder, Oliver Kummer, Manfred Olschewski, et al. Prognostic Relevance of Carbohydrate Antigen 19-9 Levels in Patients with Advanced Biliary Tract Cancer. Cancer Epidemiol Biomarkers Prev 2007 oct;16(10):2097-2100.

\section{How to cite this article?}

Vaishnav M., Garg S., Popat V. Role of ca 19-9 as a tumor marker in diagnosis and prognosis of pancreatic carcinoma and cholangiocarcinoma (A study of 46 cases). Int J Med Res Rev 2017;5(05):505-514. doi:10.17511/ijmrr. 2017.i05.12. 